\title{
Measuring Transformational Use of ICTs at Regional Level
}

\author{
Karsten Gareis and Tobias Hüsing \\ empirica \\ Gesellschaft für Kommunikations- und Technologieforschung mbH \\ Oxfordstr. 2, 53111 Bonn, Germany \\ Tel.: +49-228-98530-0 \\ E-mail: karsten.gareis@empirica.com
}

\begin{abstract}
The experience of recent years has shown that take-up of ICT, for example within strategies to implement online public services, is a necessary but not sufficient condition for making progress towards regional development goals. What is of interest is not ICT use per se, but applications of technology which exert a transformational impact on users, i.e. which support people, firms and the public sector by opening up new, more effective ways for achievement of goals rather than simply making existing structures and processes more efficient. This chapter focuses on use of ICT by individuals in their roles as citizens, workers, learners, patients, consumers, and so forth. We argue that here, the transformational potential of ICTs is rooted in its effect in terms of empowerment of users, i.e. "the process of granting people the power to take responsible initiatives to shape their own life and that of their community or society in economic, social and political terms". The chapter presents a conceptual framework for analysing ICT-enabled empowerment. It also presents some results of an Internet user survey conducted in early 2008 in 12 selected regions in the EU.
\end{abstract}

\section{Introduction}

One of the clearest challenges which Europe faces in the context of the development towards a knowledge-based society (KBS) is to improve the performance of its diverse regions. As the European Commission's strategic framework "i2010" (CEC, 2005c) has made clear, the avoidance of a regional digital divide is desirable on the grounds of both equity (social cohesion and inclusion) and of improving the overall economic competitiveness of Europe. It is increasingly accepted that bringing about an KBS will not be achieved by the market alone, but that policy intervention will be required in a number of areas - especially if the goal is to develop a KBS in which all participate in line with their needs and abilities.

Among decision-makers in EU regions, there is still confusion about how they can best tap the full potential of ICT and the knowledge economy. Likewise, most region are uncertain about how to react adequately to the challenges arising from recent paradigmatic developments such as globalisation, the network society and the new international division of labour, all of which are directly related to applications of ICT. Until now, most efforts by regional policy-makers have focussed on laying the infrastructure for ICT deployment, and on fostering the uptake of key ICTs such as the Internet by private households, businesses, the civic sector and government. Across the EU territory, significant progress has been made on both accounts. Most available evidence, however, suggests that the success in translating ICT investments into real progress in economic and social development varies considerably across regions. It remains a challenge to explain why this is the case, and what can be done about it. It is often assumed that such difference have something to do with the extent to which regions and their inhabitants are able to make transformational use of ICTs.

What do we mean by transformational uses of ICT? By means of a broad literature analysis, it was possible - in spite of the overall rather elusive way the term is used - to identify a number of core characteristics of ICT-enabled, transformational change (Cornford et al., 2006). "Transformational" is often understood as uses of ICT that open up substantially new ways for individuals, firms and governments to make progress in achieving their goals. In many cases, this refers to activities which 
would not have been possible without ICTs. In particular, three themes appear to be of key importance for the notion of transformational use of ICTs:

ü (a) It appears that the transformational potential of the Internet, mobile telephony and other ICTs resides mainly in the way these technologies enable network creation at a scale and depth not possible before. The specific properties of networks (such as network externalities), in combination with the particularities of (digital) information goods when compared to tangible goods, imply that network creation is one of the main underlying principles for ICT-enabled, paradigmatic change. In the social domain, network creation is related, in particular, to the notion of social capital (see Field, 2003).

ü (b) Given today's volatile economic and technological environment, it is of key importance to recognise and react to emergent change through the ability to exploit new opportunities. This implies the key role played by lifelong learning as a continuous, often collective process embracing the entire population, and innovation (including social innovation) for transformational change (Tuomi, 2006).

ü (c) Transformational use of ICTs, in particular at the level of individuals and communities, is often understood to be related to empowerment. The European Commission (CEC, 2005b) defines empowerment as "the process of granting people the power to take responsible initiatives to shape their own life and that of their community or society in economic, social and political terms" (p. 32).

In order to demonstrate the difference between transformational and non-transformational uses of ICT, it appears useful - at the risk of oversimplification - to think of ICT diffusion as a two-phase process (see Figure 1): In a first phase, ICT is adopted to better do what has been done before already, i.e. to increase efficiency (i.e. speed, throughput, output, variety, productivity). While significant improvements can be obtained this way, the true potential of ICTs to enable new, effective ways of doing things is not being exploited. This is what the second phase is about: Questioning traditional processes and means of achieving the fundamental goals of stakeholders, and making progress towards stronger social and networking capital, continuous learning and innovation, and empowerment of people as citizens, consumers, patients, learners and creators, to name only the most obvious roles.

Figure 1: Conceptualising ICT diffusion as a two-phase process

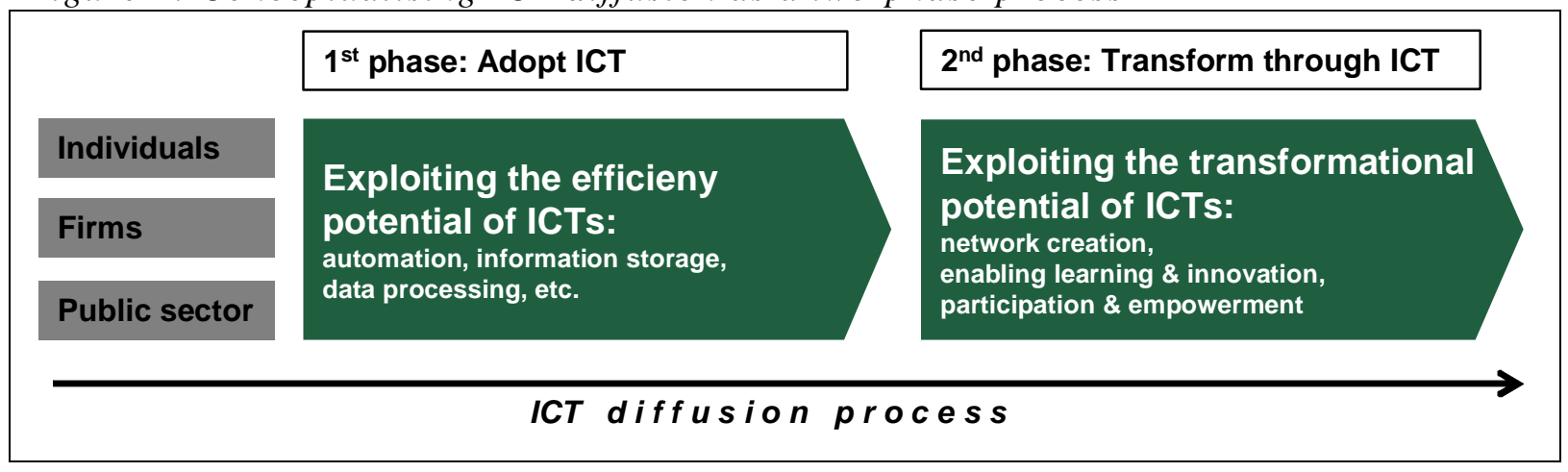

Source: The author

The purpose of this chapter is to briefly present a conceptual framework for understanding and measuring transformational use of ICTs. We will focus on use of ICT by individuals in their manifold roles. In the last part of the chapter, some results of an Internet user survey are presented which was conducted in early 2008 in 12 selected regions in the EU in order to develop insight into and to pilot indicators for capturing transformational use of ICTs by individuals. The survey data can be used to explore perceptions about the transformational effect of the Internet on individuals and the regions they are residing in. The analysis also sought to assess the extent to which certain statistical measures can be applied for the purpose of benchmarking regions according to individuals' transformational use of ICT. 


\section{Status Quo}

A number of benchmarking mechanisms have been put in place in order to monitor the progress towards the KBS in the European Union (CEC, 2005a; 2006). Benchmarking is a central component of the Open Method of Coordination and, as such, an important policy tool for EU policy-making on Information Society related issues.

The first benchmarking frameworks for ICT-related statistics were developed within the original eEurope 2002 initiative, and then further refined during eEurope 2005. Whereas most of the statistics in this early phase were still based on Eurobarometer surveys, one-off research studies or poorly harmonised national sources, lately more and more of the data have been collected by the National Statistical Institutes under the guidance of Eurostat.

The most important instrument for this purpose are the annual Information Society surveys, established in 2002 by the European Commission in view of an increasing demand for official statistics on ICT related issues within the EU (Eurostat; 2006). Indicators derived from the data were used to benchmark ICT-driven developments in enterprises and by individuals. Eurostat developed two model surveys, one on enterprises, one on individuals, in close collaboration with Member States and in coordination with initiatives within the OECD Working Party on the Information Society (OECD, 2008). These model instruments are regularly adapted to the changing needs of users and policy makers. They are composed of model questionnaires and accompanying methodological guidelines for their implementation. In 2004 the European Parliament and the Council adopted Regulation (EC) No 808/2004 covering the above mentioned surveys. As a framework regulation, it allows flexibility to adapt the surveys to newly evolving needs by users and decision makers. Annual implementing measures are forming the basis for the Eurostat model surveys and will ensure harmonized data for all EU Member States for the upcoming years.

Within the i2010 policy process, a revised set of benchmarking indicators was agreed upon in 2006 to measure progress towards achieving the i2010 goals (i2010 HLG, 2006). Indicators are grouped into nine themes: Development of broadband; Advanced services; Security; Impact; Investment in ICT research; Adoption of ICT by businesses; Impact of adoption of ICT by business; Inclusion; and Public services.

The development of indicators to benchmark the KBS on a consistent basis across the European territory marks a significant step in the evolution of European policy in the area. For the purpose, however, of benchmarking European regions' success in building up a KBS, the indicators developed to date have a number of limitations. First, they are overwhelmingly technology focused. They relate principally to the supply of and demand for ICTs and selected electronically-delivered services. Only in some cases are these supplemented by other indicators setting out the purposes for which technologies are used. Even here the indicators are usually not informed by current scientific knowledge of the determinants of (regional) social and economic development. Second, they tend to reflect an assumption that ICTs will automatically lead to economic and social development. However, we do not know that this is the case and the indicators developed to date in order to monitor ICT take-up are not sufficiently sophisticated to allow us to test this. Third, although the i2010 strategic framework acknowledges that ICTs do not diffuse uniformly across all regions and sociodemographic groups and that e-inclusion and the regional digital divide is a concern across Europe, the benchmarking exercise foreseen barely addresses the issue of regional imbalances, even within the context of the narrow technological approach outlined above. Only in the case of individuals' access to and use of the Internet are sub-national differences considered at all, and this is confined to differences between Objective 1 and non-Objective 1 regions.

\section{Towards a Framework for Measuring Transformational Use of ICT by Individuals}

For a meaningful analysis of transformation in the form of individual empowerment, a recourse to theories of human and social development is required. This bring us to Nobel price winning economist Amartya Sen. He suggests that policy-making, as far as it is concerned with social and economic 
development, should focus on the "capabilities" which people have (i.e. "entitlements based on legal rules but also socially-enforced moral rules which enable or constrain the ability to do or be certain things"), their relation to the "functionings" which they "have reason to value", and how both are affected by policy choices (Sen, 1999).

A number of authors have stressed the high relevance of Sen's work for policy choices surrounding implementation of ICTs (Mansell, 2002; Alampay, 2006). As Bianchi et al. (2006) point out, Sen's work "can substantially enrich the debate on ICT for growth and cohesion. In a nutshell, he shows that mere aggregate numbers about availability of resources, such as Internet connections, do not say much about effective empowerment of the individual and thus the productive use of the technology at societal level. Sen's normative framework therefore prompts us to switch from a technology-centred to a people-centred take on inclusion". Sen's concept for the analysis of ICT-related policies forces policy stakeholders to revisit the whole premise of why people's access to ICTs such as the Internet is deemed essential.

How, then, can we identify and conceptualise activities which are potentially transformed by ICTs, and how can we make sense of their 'empowering impact'? A useful starting point is the work of Nurmela et al. (2004), who have developed a framework for the analysis of individuals' use of ICT based on extensive empirical research with focus groups. The authors distinguish seven spheres of application of ICTs by private households/individuals.

For the purpose of analysing the utility which individuals derive from these activities, application of the media-system dependency goals identified by Ball-Rokeach (1985) appears to be of special interest.

Jung et al. (2001) based their "Internet Connectedness Index" on this approach. They came up with six main goals with regard to the use of Internet and other ICTs:

ü Two understanding goals: to stay on top of events and groups that you care about (social understanding); to express yourself or your opinions (self-understanding);

ü Two orientation goals: to accomplish business, financial, or work tasks (action orientation); to get advice on how to deal with other people, such as doctors and other health professionals (interaction-orientation);

ü Two play goals: to play or amuse yourself (solitary play); for social reasons like making new friends (social play).

For the purpose of the present paper, we define these six goals as "objective functions". Based on these and other similar categorisations, we identified seven areas of 'everyday life activities' which are directly affected by key applications of ICT (see Table 1). These are: to communicate (social interaction); to receive \& process information and to learn; to take care of personal business, transactions and requests for help; to enjoy entertainment; to generate and distribute own content; to participate in policy-making and public life; and to engage in employment-related activities. Each of these activities is associated with one or several objective functions as described above.

Table 1: Spheres of ICT application by individuals

\begin{tabular}{|c|c|c|}
\hline Activity & Applications of ICT (Examples) & Users' Objective Function \\
\hline $\begin{array}{l}\text { Communicate (social } \\
\text { interaction) }\end{array}$ & $\begin{array}{l}\text { e-Mail, mobile phone, SMS, messaging services, IRC } \\
\text { chat, social network services, location-based services, } \\
\text { and so forth }\end{array}$ & $\begin{array}{ll}\text { ü } & \text { Social play; } \\
\text { ü } & \text { Social understanding; } \\
\text { ü } & \text { Self-understanding } \\
\text { ü } & \text { Interaction-orientation } \\
\text { ü } & \text { Action orientation }\end{array}$ \\
\hline $\begin{array}{l}\text { Receive \& process } \\
\text { information, and learning }\end{array}$ & $\begin{array}{l}\text { Passive: PC and mobile device, Digital /interactive } \\
\text { TV and radio, Internet information portals, streaming } \\
\text { radio, podcasting, blogging } \\
\text { Active: search engine, discussion boards, } \\
\text { communities of interest, eLearning services, location- } \\
\text { based services, and so forth }\end{array}$ & $\begin{array}{ll}\ddot{u} & \text { Social understanding; } \\
\text { ü } & \text { Interaction-orientation; } \\
\text { ü } & \text { Action orientation; } \\
\text { ü } & \text { Self-understanding }\end{array}$ \\
\hline Take care of personal & PC and/or mobile device, Internet, mobile phone, & ü Action orientation \\
\hline
\end{tabular}




\begin{tabular}{|c|c|c|}
\hline Activity & Applications of ICT (Examples) & Users' Objective Function \\
\hline $\begin{array}{l}\text { business, transactions and } \\
\text { requests for assistance }\end{array}$ & $\begin{array}{l}\text { SMS, 3G-phone, online banking software, } \\
\text { spreadsheet programme, security software, patient- } \\
\text { sided eHealth services, location-based services, and } \\
\text { so forth }\end{array}$ & \\
\hline Entertainment & $\begin{array}{l}\text { Latest generation PC or mobile device, gaming } \\
\text { software, multimedia software, broadband Internet, } \\
\text { peripherals }\end{array}$ & $\begin{array}{ll}\text { ü } & \text { Solitary play; } \\
\text { ü } & \text { Social play }\end{array}$ \\
\hline $\begin{array}{l}\text { Generate and distribute } \\
\text { own content }\end{array}$ & $\begin{array}{l}\text { PC, digital camera, Internet, multimedia software, } \\
\text { publishing software, podcasts, blogging }\end{array}$ & $\begin{array}{ll}\ddot{u} & \text { Self-understanding; } \\
\text { ü } & \text { Solitary play; } \\
\text { ü } & \text { Social play } \\
\end{array}$ \\
\hline $\begin{array}{l}\text { Participate in policy- } \\
\text { making and public life }\end{array}$ & $\begin{array}{l}\text { PC and mobile device, Internet, discussion boards on } \\
\text { communities of interest, IRC chat, social network } \\
\text { services }\end{array}$ & $\begin{array}{ll}\ddot{\text { ü }} \text { Self-understanding; } \\
\text { ü } & \text { Social understanding }\end{array}$ \\
\hline $\begin{array}{l}\text { Employment-related } \\
\text { activities }\end{array}$ & $\begin{array}{l}\text { Office applications, specialist software, Internet, } \\
\text { Intranet, communities of practice, peripherals, CSCW } \\
\text { tools, social network services, PDA, mobile } \\
\text { telephony, location-based services, and so forth }\end{array}$ & ü Action orientation \\
\hline
\end{tabular}

Source: The author

It is now possible to show for each of these activity areas to what extent ICTs - in the form in which they have developed, which itself is a socially constructed process, see MacKenzie \& Wajcman, 1999) - have the inherent potential to offer fundamentally new ways for achieving the objective functions associated with particular activities. For the purpose of benchmarking, we need to ask for each of the seven spheres of activities to what extent certain uses of the Internet and other ICT constitute a transformational use of technology, according to our understanding of the term as outlined above.

\section{Communication and Social Interaction}

Techno-social innovations which give rise to fundamentally new communication channels and tools can be expected to play a potentially transformational role, simply because of the essential role which communication plays for human society. Without any doubt, the Internet belongs into this category, as does mobile telephony (which tends to be less often acknowledged, see Tuomi, 2002; Sheller \& Urry, 2006). Both of these technologies are in the process of becoming ubiquitous, which Castells et al. (2004) argue means nothing less than a homogenisation of space: "being ubiquitous means transcending space" (p. 236). Obviously, this has far-reaching consequences for social interaction.

Katz \& Rice (2002) define social interaction as "focused on individual relations and goals", in contrast to civic and community involvement ("participation in a jointly produced social, civic, or community activity"). Social interaction "entails interaction with specific others whom one either knows initially or eventually comes to know. This interaction is likely to involve dyadic, familial, friendship, romantic, and group relations. [Compared to social participation] it speaks less directly to the interests and goals of collectives" (p. 32).

Analysis of the effect of technology on patterns of social interaction is related, of course, with the debate about social capital. Social capital is sensibly defined by Field (2003) as follows: "By making connections with one another, and keeping them going over time, people are able to work together to achieve things that they either could not achieve by themselves, or could only achieve with great difficulty. People connect through a series of networks and they tend to share common values with other members of these networks; to the extent that these networks constitute a resource, they can be seen as forming a kind of capital" (p. 7).

Whereas the notion of social capital has generally being considered in the policy process as something positive for those who are endowed with it (CEC, 2005b), closer analysis reveals the need for distinguishing between three different types (Nahapiet \& Ghoshal, 1998):

ü bonding social capital, i.e. strong ties between like people (or organisations) in similar situations;

ü bridging social capital, i.e. more distant or "weak ties" of like persons (or organisations); 
ü linking social capital, i.e. weak ties which reach out to unlike people/organisations, such as those which are entirely outside of the community or in a different sector.

Some authors have suggested, based on the seminal work of Granovetter (1973), that it is the latter two types of social capital which appear to be of most importance as determinants of success in the knowledge-based economy and society (Boase et al., 2006).

Against this background, an increasing number of commentators and researchers have pointed out that the Internet can play a decisive role in transforming access to social capital as well as the capability to translate stocks of social capital into personal benefits.

Among the ICTs which are being discussed in this context are simple applications such as e-mail one of the Internet's killer applications, as it has been driving people online just to be able to participate in electronic communication - but also "virtual communities" (Rheingold, 2000) and participative web services, usually subsumed under the term Web 2.0. It describes applications of the Internet which comprise a strong degree of user involvement, such as in the case of the popular social networking sites which combine traditional means of online communications (discussion boards, online chat, e-mail) with the possibility to upload and share (often self-created) content, to identify people with similar interests, and to easily find content or users which is likely to be relevant, for example by implementation of rating and "tagging" of pieces of content. In spite of the criticism which the hype around the Web 2.0 applications has attracted, there is widespread consensus that the Internet has indeed become a powerful instrument for user involvement and an outlet for creativity (Benkler, 2006; OECD, 2007; Tapscott \& Williams, 2007). The rapid diffusion of such applications point towards an increasing range of possibilities for Internet-based social innovations to transform patterns of sociability.

In a similar way, the diffusion of mobile telephony has exceeded all expectations as users have quickly grasped the possibilities which it offers them to do things they value highly, but could not do before (Castells et al., 2004; Ling, 2008). Most importantly, users of mobile phones are independent from stationary connections, i.e. they can make phone calls and send text messages from practically anywhere. The implication is that people enjoy considerably enhanced control over the communication process. But this is far from the only major transformational effect which is ascribed to wireless communication systems. The arrival of the third generation of mobile telephony, especially of fast UMTS-connections and the increasing functionality of mobile phones (integrating features of personal information managers, cameras, digital music players, and so forth) will also open up new possibilities and further heighten the transformational potential of this kind of applications.

In order to analyse the transformational impact of these ICTs with regard to activities related to communication and social interaction, we need to ask whether these technologies have exerted a significant influence on the quality and quantity of social interaction. More concretely, transformation could be linked to evidence of significant increases in:

ü the number of weak ties between individuals (bridging social capital);

$\ddot{u}$ the diversity of social ties between individuals (linking social capital);

ü levels of social capital as measured by belonging to social groups as well as active participation in discussions and decision-making within social groups;

ü the creation of new weak ties among those who traditionally suffered from low levels of social capital;

ü the degree to which individuals are able to benefit from their social ties by gaining access to resources when these are needed (Dutton, 2005).

For the discussion of the social impacts of ICT, it is necessary to take into account that ICT-enabled "networked individualism" (Castells, 2001) is developing as part of longer-term trend, by which the community as a social construct - based primarily on face-to-face interaction and as such bound to a limited geographical territory, such as a neighbourhood - has been loosing much of its relevance. This process started long before the advent of ICTs and the Internet (Wellman, 2001). 


\section{Reception and Processing of Information, and Learning}

The perception of information from the mass media remains one of the basic purposes of media consumption, including use of the Internet. Increasingly, however, the progressive convergence between previously separated media spheres, strongly influenced by the further development of the Internet, has made traditional distinctions, such as mass media versus individual/personal media, more and more meaningless. Today, most experts observe a gradual shift towards what is called "mesomedia" (Feldmann \& Zerdick, 2005), with mass media becoming more personalised (e.g. though increasing number of specialist channels, digital television with heightened interactivity) and personal media being opened up to larger numbers of the public (e.g. through online chats, discussion forums, blogging).

Concerning information offered for active retrieval by individuals, it is safe to say that the Internet has made a huge difference to the accessibility of information. People who are equipped with the adequate skills in identifying, selecting and processing information enjoy the benefits of almost instant access to an incredible wealth of data on the Internet. As opposed to the pre-Internet era when most mediated information was transmitted through the mass media, the Internet enables high degrees of personalisation of information retrieval. The huge leaps in performance which search engine technology have made in recent years have provided users with adequate tools to exploit this richness of information.

The question is now whether these developments constitute a transformation of previous practice, or simply an acceleration. It is certainly true that just enabling people from different backgrounds (e.g. different nations, cultures) to exchange information freely between each other will not necessarily yield meaningful outcomes. Many Internet users might be much less interested in learning new things, but in finding confirmation for opinions they already hold and in contacting people which they feel are "like them" (Katz \& Rice; 2002). It has been noticed that the possibility for personalising the information which one is exposed to may lead to narrow-mindedness and social fragmentation. Indeed, Katz \& Rice (2002) report from a evidence that levels of selective exposure to news are significantly higher for Internet users than for newspaper readers and viewers of TV news. As a consequence, Hill \& Hughes (1998) claim that "people go on-line to find out more information about a subject, not to be transformed".

There are, however, also many signs of truly transformational practice. Online communities of practice are of particular importance in this regard. The experience of recent years certainly gives credibility to the claim of Manuel Castells (2001) who states that virtual communities of practice are an expression of the latent existence of common interests and/or values between people who do not know each other, but who could derive personal utility from interaction. This suggests that there are good reasons to use engagement in online communities of interest and participation in social network platforms as indicators for transformational use of ICTs. More research is, however, certainly needed before such indicators can be used for benchmarking.

A more obvious incidence of transformational use of technology is ICT-enabled participation in lifelong learning. The case for transforming structured learning and training into a lifelong activity has been made powerfully by academics and policy-makers alike (e.g. OECD, 2001). Evidence of this happening is, unfortunately, very limited indeed. In particular, there is little progress in achieving higher rates of participation in lifelong learning within those sub-groups of the population which are at risk of social exclusion (van Dijk, 2005). Any use of ICT which achieves engagement in lifelong learning by those who otherwise would not participate in such activities can without doubt be called "transformational".

With regard to the traditional obstacles which affect people who are willing to engage in learning activities, eLearning applications offer a lot of potential. Data from a representative survey conducted by eUSER (2006) suggest that a sizeable minority of people currently engaged in online eLearning courses would not have been able to engage in training if it was not for the possibility to do this online - again, an example of truly transformational application of ICTs. 


\section{Personal Business, Transactions and Requests for Assistance}

Instrumental uses of ICTs in the private domain include transactions such as online banking, online ordering and reservations, as well as many e-government applications. In general, we can observe increases in control of consumers over activities of a transactional nature, reaching from simple personalisation of products enabled by Internet technologies to instances of full-fletched codevelopment of goods and services, in which consumers become "prosumers" who have a strong influence on how the products they purchase look like and work.

ICTs have opened up a whole range of new possibilities for people whose ability to take care of personal business and transactions used to be constrained - for example because of lack of time, because of individual functional restrictions, or because of geographical location in a peripheral or otherwise disadvantaged region of Europe.

While increased convenience alone should not be confused with transformational change, in some cases such changes may exert a strong impact on the ability of people to lead a self-determined life. It appears futile to try to draw a clear line between non-transformational and transformational applications of ICT in this area.

One of the more fascinating effects of the Internet has been the evolution of online trading and selling between private households through the Internet, mainly by means of online auctions. The Internet, together with other ICTs, has made a big impact on the ease and flexibility with which such tasks can be carried out. The basic underlying reason can be found in transaction cost theory. As was noted by the early transaction cost theorists already, transaction costs can be altered by technological progress. ICTs in general, and the Internet, in particular, have been shown to reduce the costs of many types of transactions (Malone et al., 1987; Picot et al., 2003; Cordella, 2006). An important component of the transaction costs that are incurred by activities for acquiring information are search costs. These arise when market participants have to invest in activities to find the information they need to decide how to behave on the market, e.g. to take part in the labour market or stay out. Search costs are determined by the nature, number and intensity of search activities, but also by the technique and technology used for investigating information. For this reason, ICTs have a major influence on search costs, not only on their overall level, but also on their composition and the relative costs of different search techniques. In that way, the Internet has transformed the marketplace by enabling the emergence of new markets which have not been sustainable before, because transaction costs were prohibitive - a typical example of market failure which the Internet and other ICTs were able to abolish.

"Requests for assistance" here refers to instrumental use of the ICT in cases of need or emergencies. Any improvements in access to health- and emergency-related services are obviously of highest relevance to the capability of people to lead a self-determined and healthy life (Murero et al., 2006).

\section{Entertainment}

"Users have a tendency to twist new technology to fulfil their interests or desires", as Castells (2001, p. 54) writes. The Internet, mobile telephony and the other new ICTs are certainly no exceptions in this regard. Because of our focus on uses of ICT relevant for regional development and society at large, entertainment applications are of less interest to us. Note, however, that boundaries between ICT-based entertainment activities and other domains, such as learning, social interaction and communication, distribution of own content, and even employment, are becoming increasingly blurred (Castronova, 2005). Of special relevance are gaming applications which help overcome barriers to engagement in lifelong learning, especially among those people which are generally considered to be averse to formal education and training courses. Such "serious games" (Annetta, 2008) have attracted a lot of interest by practitioners in the adult education domain. If such online games are taken up by parts of the population which are unlikely to be reached by traditional training offers, we can speak of a transformational impact.

\section{Generation and Distribution of User-Created Content}

The Internet and (increasingly) also mobile networks offer unprecedented possibilities for the distribution of user-created content (OECD, 2007). This appears - in contrast to other uses of the 
Internet such as information retrieval and one-to-many entertainment - to represent a fundamentally new way of people to interact with public media (Zittrain, 2006).

In the early years of this decade, many experts shared the observation by Nurmela et al. (2004) that "the need now is for various kinds of forums where citizens could build up the courage they need to put up their own production on display" (p. 14). Castells (2001) wrote "the most important latent demand [is ] for interactive free expression and autonomous creation - nowadays largely stymied by the sclerotic vision of the traditional media industry" (p. 200).

Since then, the runaway success of Internet services such as MySpace, Linked-In and YouTube has confirmed that there is a big interest from users in publishing self-created content on the Internet (Benkler, 2006). Open source systems, decentralised broadcasting, serendipitous interaction, commoninterest communication, and co-creation have all become mainstream uses of ICTs. In this context, Katz \& Rice (2004) apply the term "Internet enabled expression" which "refers to the material that is created by individuals or groups to reflect their views, interests, or talents. These materials are produced for the observation, interest, or response of their creators and, usually, others" (p. 5). This definition clearly points towards the overlap between self-generated content and civic and political participation (see below).

For the moment, it appears that indicators which measure active contribution to social network services and similar applications can be good proxies of transformational use of ICT in the form of exchange of user-created content.

\section{Participation in Policy-Making and Public Life}

From early on, there have been claims that the Internet would play a considerable role in fostering democracy through enhanced participation of citizens in the policy-making process - especially at the local and regional levels of government. As a number of leading scholars (e.g. Tuomi, 2002) have shown, the development of the Internet itself owes much to a fundamentally open, democratic process of social production. It is hardly surprising, then, that futurist authors have seen in the Internet a potentially giant step forward towards a truly democratic society.

Only in recent years, however, e-participation emerged on the public agenda, itself drawing on three developments: (a) Development and implementation of CSCW (Computer Supported Cooperative Work) and groupware, which make use of latest-generation ICTs to enable and support collaborative human interaction; (b) Increasing interest in what is termed e-democracy (earlier: tele-democracy) since the late 1990s, when the focus shifted rapidly from eVoting to several forms of ICT-supported and ICT-enabled interaction between governments and citizens; (c) The evolution of e-government developments towards increasingly complex service delivery.

While the issue of e-voting has all but disappeared from the political agenda in most EU countries, the pace of techno-economic change, as indicated by the rapid diffusion of broadband access to the Internet, and the spread of online social networking mean that the possibilities to let citizen participate in policy-making have, arguably, never been as good as today. At the same time, concerns about increasing numbers of citizens becoming disengaged with the political process have been growing in recent years.

As in the case of e-learning, we can distinguish between two types of transformational use with regard to online participation in policy-making: First, people who are already interested in politics and society at large may be offered tools for higher-quality participation in policy-making: Second, and even more importantly, citizens who up to now have not been willing to engage in civic participation may be stimulated to take an active role.

Care needs to be taken, however, for benchmarking activities concerning political participation. Judgemental and normative statements about the relationship between Internet usage and the democratic process need to be based on a common understanding of the meaning of the term "democracy". The existence of such a consensus cannot be taken for granted. Dahlberg (2001) distinguishes between three idealised forms of democracy (liberal individualism, communitarism and deliberate democracy) and shows that, depending on the interpretation of democracy a person 
subscribes to, she or he will judge the potential and actual impact of the Internet on democracy in very different terms.

\section{Worker Empowerment and Organisational Change}

We can sketch the development of the public debate about transformational impact of ICTs in organisations as follows: Starting from an early phase in which the focus was on technology per se, via a backlash phase in the aftermath of the dot.com crash, in which the positive effect of ICT on performance was put in doubt in general, the scientific and public debate has now reached a consensus that ICT does indeed matter, but that its introduction needs to be embedded in a wider strategy of organisational change. Confirmation comes from a rich body of research which has appeared since the mid 1990s (OECD, 2001, 2004; Smith \& Fingar, 2003).

This means that, while most models of ICT-enabled progress in companies focus on how ICT 'drives' organisational change, complementary organisational change is required to 'unlock' the powers of ICT. Such a strategy needs, more than anything else, take full account of the central role which the workforce plays in making successful change happen (Malone, 2004).

For analysing such processes of organisational change (and the degree to which they amount to "transformational change"), it appears useful to refer to the research about what has been called "new forms of work organisation", "new organisation of work" or "modernisation of work organisation" (Nordflex, 1999). A widely used definition for these was adopted by the European Work Organisation Network (Savage, 2001): "New Work Organisation is the application of principles and practices within enterprises which aim to capitalise on, and develop the creativity and commitment of employees at all levels in achieving competitive advantage and in meeting the business and service challenges posed by the social, economic and technological environment in which the enterprise exists" (p. 5).

We can observe transformational use of ICT within the domain of work and employment in cases where the implementation of ICT systems significantly increases the extent to which workers are participating in decisions about their working conditions. Indicators measuring characteristics of workplaces, including participation in such decisions, are collected in many countries through national employee surveys (Huys \& Ramioul, 2007). Comparisons across countries are possible in Europe by using the data from the European Working Conditions Survey (Parent-Thirion et al., 2007).

\section{Some Evidence from A 12-Region Internet User Survey in Europe}

As discussed above, most existing statistics on the use of ICTs by households - especially those few ones which are available at the regional level within Europe - focus on basic readiness and uptake of ICTs rather than the value which people and organisations derive from using the Internet, mobile telephony, and other ICTs. In recent years, however, scientific research including work at publicly funded research centres such as the Oxford Internet Institute (Dutton \& Helsper, 2007) and the Pew Internet \& American Life Project (Boase et al., 2006), as well as research by National Statistical Institutes (e.g. Harper \& Kelly, 2003; Nurmela, 2006) has made progress in identifying and measuring the ways in which the Internet and other ICTs exert a direct, and arguably transformational, influence on people's lives. This is the background against which in the following results from an indicator piloting survey are presented. The survey has provided data with which some of the issues surrounding transformational use of ICT in the seven areas of 'everyday life activities' introduced in the previous section can be explored in more depth.

\section{Methodology for Data Collection}

The data were obtained through an online survey of Internet users in 12 NUTS2 regions in 7 countries of Europe (Germany, Italy, Poland, Slovakia, Spain, Sweden and United Kingdom). Data collection was centrally managed and programmed, and made use of the Ipsos Online Access Panel and equivalent panels of partner institutes. The Ipsos Access Panels comprise more than 1 million consumers in over 20 countries, and are in full compliance with the international standards for online 
access panels defined within EFAMRO, the international federation of market research agency associations.

For the survey, a stratified random sample was drawn, with quotas being applied to make sure that certain types of individuals are adequately represented in the sample. For building the sample, a quota sampling approach was used in order to create a sample representative for the target group, i.e. regular Internet users aged 18-64 regarding age, gender and region. The quotas were created by obtaining the universe figures from two sources; Eurostat 2006 for Slovakia, Poland and Sweden and offline representative studies (CAPIBUS) that were provided by partner institutes of Ipsos in United Kingdom, Spain and Italy as well as used for Germany. In case of over/under-achievement of quotas, ex-post weighting of cased was used to correct for the deviation.

The questionnaire included a larger number of questions grouped into six modules: sociodemographics, entrepreneurial experience, Internet use, ICT skills \& training, social activities \& civil participation; social ties \& networking. The instrument was pre-tested in the laboratory and in the field prior to start of the data gathering phase.

The data gathered were then analysed using the SPSS software package in order to assess the validity of measurement, comparability across cultures (i.e. countries, language areas), statistical relevance (explanatory power) and cost efficiency.

Note that the sizable differences regarding the share of regular Internet users within the population aged 18-64 between the countries covered by the survey - in particular, between the Old and the New Member States - imply that the socio-demographic composition of the universe (i.e. age, employment and social status distribution) also differs quite extensively between the countries in the sample. In general, the universe in the countries with comparatively low Internet diffusion (Italy, Poland, Slovakia) tends to be younger and better educated compared to the other countries. This needs to be taken into account when comparing the results between regions.

Table 2 includes a number of key indicators which describe the regions selected for the survey.

Table 2: Key indicators on regions covered by survey ${ }^{l}$

\begin{tabular}{|c|c|c|c|c|c|c|c|}
\hline \multirow[b]{2}{*}{ Region } & \multirow{2}{*}{$\stackrel{\vec{E}}{\Xi}$} & \multicolumn{2}{|c|}{ Population } & \multicolumn{2}{|c|}{ GDP/head in PPS } & \multirow{2}{*}{$\begin{array}{l}\text { Unemploy- } \\
\text { ment rate } \\
(\%, 2005)\end{array}$} & \multirow{2}{*}{$\begin{array}{c}\text { HRST (\%, } \\
2005)\end{array}$} \\
\hline & & $\begin{array}{c}\text { Total } \\
\text { (2004) }\end{array}$ & $\begin{array}{l}\text { Density } \\
(2003)\end{array}$ & $\begin{array}{c}\mathrm{EU} 25=100 \\
(2003)\end{array}$ & $\begin{array}{l}\text { \% Change } \\
1999-2003\end{array}$ & & \\
\hline Pomorskie & PL & 2191.5 & 120 & 46.3 & -0.2 & 18.9 & 29 \\
\hline Malopolskie & $\mathrm{PL}$ & 3256.6 & 214 & 40.4 & 0.5 & 15.2 & 31 \\
\hline Bratislavsky Kraj & SK & 600.5 & 292 & 115.9 & 13.9 & 5.3 & 55 \\
\hline Východné Slovensko & SK & 1565.6 & 99 & 38.8 & 3.5 & 23.1 & 27 \\
\hline Schleswig-Holstein & $\mathrm{DE}$ & 2826.0 & 179 & 98.3 & -7.5 & 10.3 & 46 \\
\hline Thüringen & $\mathrm{DE}$ & 2364.2 & 147 & 75.2 & 0.1 & 17.2 & 53 \\
\hline Mellersta Norrlland & SE & 371.7 & 5 & 105.5 & -1.5 & 8.2 & 43 \\
\hline Emilia Romagna & IT & 4080.4 & 191 & 137.0 & -8.8 & 3.7 & 31 \\
\hline Navarra & ES & 576.8 & 55 & 123.1 & 9.0 & 5.6 & 53 \\
\hline Extremadura & ES & 1067.5 & 26 & 63.8 & 3.6 & 15.8 & 33 \\
\hline South Yorkshire & UK & 1278.8 & 816 & 89.4 & 6.7 & 5.3 & 32 \\
\hline East Anglia & UK & 2239.9 & 176 & 106.8 & 6.0 & 4.1 & 39 \\
\hline
\end{tabular}

Data source: Eurostat REGIO database

\section{How Important are Different Uses of the Internet for the Lives of People?}

The extent to which the Internet "makes a real difference" to people's lives can be explored by looking at people's perceptions. Whereas most indicator systems which are currently in use attempt to measure

\footnotetext{
1 Indicator definitions: Annual average population in 1000, 2004; Population density: Inhabitants per km² in 2003; GDP per inhabitant (in PPS), EU25=100, 2003; Change of GDP per inhabitant (in PPS) in percentage points of the average EU25, 2003 as compared with 1999; Unemployment rate, 2005; Human Resources in Science and Technology (HRST) in percent of labour force 2005.
} 
whether individuals have used certain applications of the Internet, the survey presented respondents with a list of possible uses of the Internet and then asked how important these are perceived to be for (a) their private life and (b) - using a somewhat different list of items - their ability to carry out their job (if in employment). Table 3 presents the results for importance for private life.

Table 3: The perceived importance of the Internet for private life

\begin{tabular}{|l|c|c|c|}
\hline & $\begin{array}{c}\text { Percent saying } \\
\text { this Internet use } \\
\text { is of essential } \\
\text { importance for } \\
\text { their lives }\end{array}$ & $\begin{array}{c}\text { Percent saying } \\
\text { this Internet use } \\
\text { is of high } \\
\text { importance for } \\
\text { their lives }\end{array}$ & $\begin{array}{c}\text { Importance of } \\
\text { this Internet use } \\
\text { for private life: } \\
\text { on }\end{array}$ \\
\hline To use your bank's online services & 44.1 & 66.1 & 3.44 \\
\hline To communicate with people outside of the region & 38.0 & 63.2 & 3.49 \\
\hline To communicate with people in the region & 35.4 & 58.9 & 3.72 \\
\hline To communicate with people abroad & 34.2 & 52.9 & 4.28 \\
\hline For educational and learning purposes & 28.1 & 57.4 & 3.70 \\
\hline To find info about sth. you consider buying locally & 27.4 & 62.1 & 3.49 \\
\hline To work at home & 26.3 & 47.2 & 4.67 \\
\hline To look for career related information in general & 21.4 & 49.0 & 4.32 \\
\hline To look for career related info from region or city & 19.4 & 46.5 & 4.48 \\
\hline To look for news about region or city & 17.7 & 46.2 & 4.30 \\
\hline To buy or order goods and services & 17.3 & 49.5 & 4.16 \\
\hline To obtain info about events in region or city & 17.1 & 48.6 & 4.13 \\
\hline To find info about health issues in general & 14.4 & 41.2 & 4.49 \\
\hline To find info about health services in region or city & 13.6 & 36.9 & 4.80 \\
\hline To play online games & 9.4 & 21.4 & 6.67 \\
\hline
\end{tabular}

We found that the majority of Internet users consider many of the uses they make of the Internet as being of essential or at least high importance. Commercial functions such as online-banking and prepurchase information seeking about products and services are among the uses considered as most important, which suggests that applications which mainly increase the convenience of transactions i.e. not considered as transformational in the previous section - are perceived by Internet users as highly relevant.

Information sources which are specific to the resident region are given - on average - roughly the same weight as non-region specific information sources. While it can be assumed that there are big differences between the quality of region-specific information made available online, which includes online public services, our data suggest that Internet users tend not to distinguish between regionspecific and non-specific information sources.

By means of a factor analysis ${ }^{4}$, the 15 items could be reduced to four factors, each of which represents types of Internet usage which are typically given roughly the same importance by respondents. The four factors are:

ü “To play online games” appeared as a separate factor [Online gaming];

ü A second factor includes "To buy or order goods and services", "To use your bank's online services" and "To find information about goods or services which you consider buying at shops in your region or city". These are instrumental uses with a clear focus on commercial transactions [Commercial];

\footnotetext{
2 Value " 1 " on 10-point scale $(1=$ essential, $10=$ not important at all $)$

3 Values " 1 " to " 3 " on 10-point scale $(1=$ essential, $10=$ not important at all $)$

4 The factor analysis was done using the SPSS statndard procedure, extraction method: principal components, varimax rotation and using the eigenvalue $>1$ criterion. Factor scores were calculated using regression method.
} 
ü A third factor includes "To communicate with people located in the same region", "To communicate with people located outside of the region but inside country", "To communicate with people located abroad", "To work at home" and "For educational and learning purposes". These uses relate to online communication and to instrumental uses concerned with work and learning [Communication, work \& studies];

ü The final factor includes "To find information about health and medical care services in your region, city or neighbourhood", "To find information about health issues in general", "To look for news about your region, city or neighbourhood", "To obtain information about events in your region, city or neighbourhood", "To look for career related information from your region, city or neighbourhood" and "To look for career related information (jobs, information related to your work) in general". These are uses which have to do with information that in earlier times would have been sought in newspapers, specialist magazines and reference books. [General information search].

Subsequently, these factors were used as independent factors in a regression analysis (see below).

In order to explore whether the Internet has made a difference to the ease of maintaining weak ties, the survey asked respondents directly whether they think that the Internet has had an effect on the number of people they communicate with at least occasionally. This is a very simple operationalisation of the notion of "weak ties" as suggested by Granovetter (1973). In line with the theory-based assumptions according to which the Internet is likely to increase the number of weak ties by diminishing the costs of keeping in (loose) contact with a large number of people (Boase et al., 2006), the data shows that one in two respondents felt the Internet has increased their number of private weak ties within the region as well as within the country. $46 \%$ also felt an increase in occasional contacts with people abroad. For all of these types of contacts, the share of respondents who perceive a strong increase as a consequence of the Internet is between one in four and one in five.

For another piece of analysis, we applied a methodology developed by the Pew Internet \& American Life Project (Boase et al., 2006): Interviewees were presented with a list of items describing what can be termed "major decisions in life" (see Table 4). For each of these decisions, we first enquired whether respondents had to deal with it in the reference period, in which case they were then asked what role the Internet played for dealing with the decision.

Table 4: The role of the Internet for major decisions in life

\begin{tabular}{|l|c|c|c|c|}
\hline & $\begin{array}{c}\text { Percent of } \\
\text { Internet users } \\
\text { who dealt with } \\
\text { this issue in last } \\
3 \text { years }\end{array}$ & $\begin{array}{c}\text { Percent of those } \\
\text { who dealt with } \\
\text { issue for which } \\
\text { Internet played } \\
\text { an essential role }\end{array}$ & $\begin{array}{c}\text { Percent of those } \\
\text { who dealt with } \\
\text { issue for which } \\
\text { Internet played } \\
\text { an important } \\
\text { role }\end{array}$ & $\begin{array}{c}\text { Importance of } \\
\text { the Internet for } \\
\text { dealing with } \\
\text { issue: Mean on } \\
\text { 10-point scale }\end{array}$ \\
\hline $\begin{array}{l}\text { Made a major investment or } \\
\text { financial decision }\end{array}$ & 46.1 & 25.1 & 50.8 & 4.43 \\
\hline $\begin{array}{l}\text { Gotten additional education or } \\
\text { training for your career }\end{array}$ & 48.4 & 25.3 & 51.7 & 4.27 \\
\hline $\begin{array}{l}\text { Chosen a school or college for } \\
\text { yourself or your child }\end{array}$ & 32.9 & 28.4 & 53.6 & 4.25 \\
\hline $\begin{array}{l}\text { Helped another person deal } \\
\text { with a major illness }\end{array}$ & 38.0 & 19.3 & 39.4 & 5.21 \\
\hline Moved into a new place to live & 31.1 & 23.1 & 38.9 & 5.47 \\
\hline Changed jobs & 34.5 & 29.5 & 48.8 & 4.71 \\
\hline
\end{tabular}

5 Value "1" on 10-point scale ( 1 = essential, $10=$ not important at all $)$

6 Values " 1 " to " 3 " on 10-point scale $(1=$ essential, $10=$ not important at all $)$ 
The results clearly show how that the Internet does indeed play a highly significant role in decisions which are transformative in character. About one in four Internet users who have been face with major decisions about financial issues, education \& training for themselves or their children, moving place or changing jobs state that the Internet was of essential importance for dealing with the issue. Somewhat less than one in five of those who have been helping another person deal with a major illness or health condition considered the role of the Internet as essential. If considering all of those who indicated a high importance of the Internet in the process, figures are around 50\% for all listed "major decisions" with the exception of "helping another person deal with a major illness" and "moved into a new place to live", for which somewhat less than $40 \%$ indicate that the Internet was of major importance. These results also indicate that local and regional public agencies can indeed play a powerful role in helping citizens deal with potentially transformational decision in life, by offering online public services (in key areas such as health, education \& training, jobs and accommodation) which meet the needs and preferences of users.

\section{Participative Web Applications}

Our survey included a question on what are sometimes advanced Internet services, or Web 2.0 applications. The results (see Figure 2) suggest that the share of Internet users who actively contribute to the Internet, including uploading of user-created content, is indeed considerable.

\section{Figure 2: Uptake of advanced Internet applications}

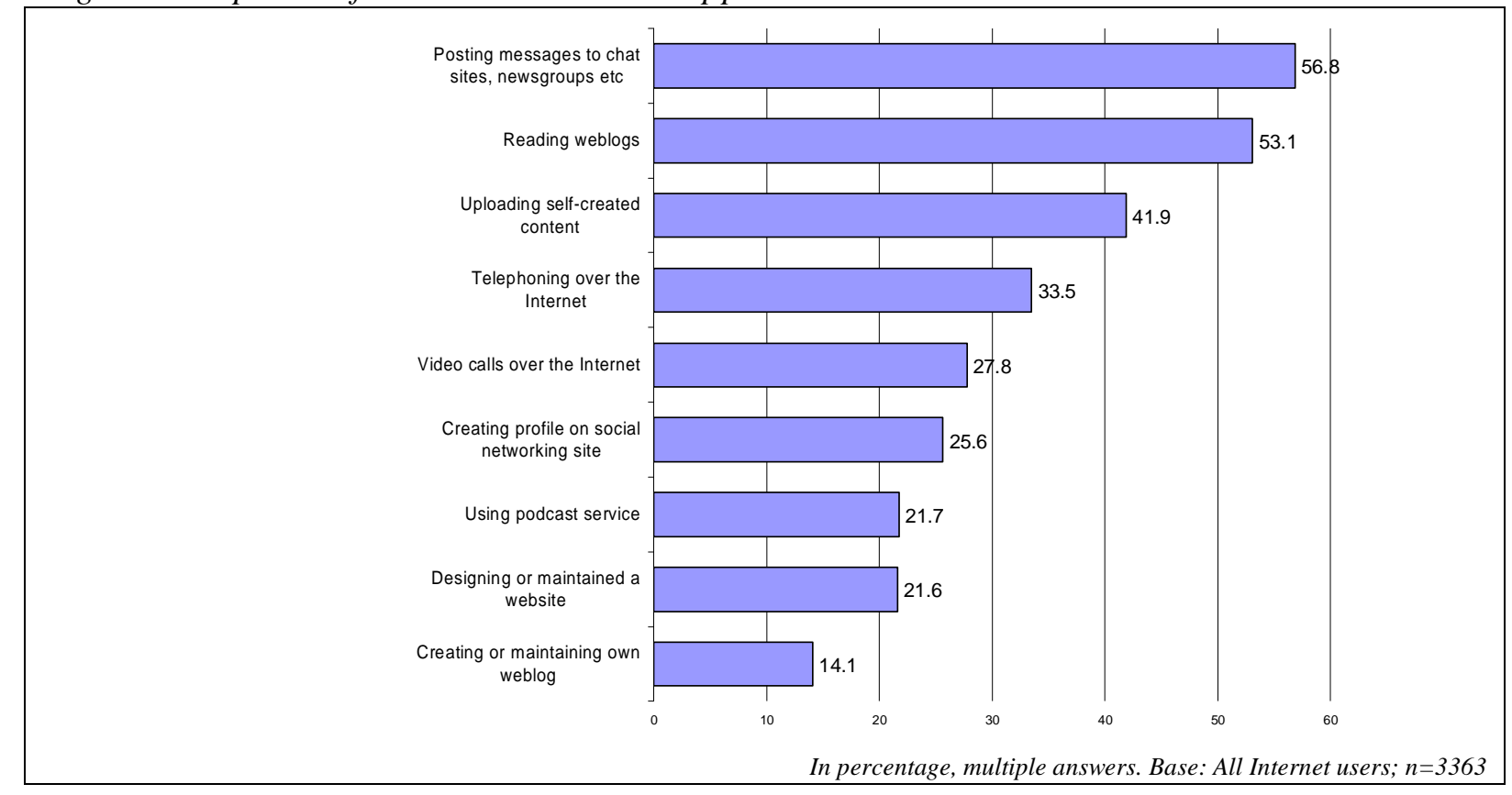

Data source: TRANSFORM 12 Region Internet User Survey

57\% have, in the 3 months prior to the survey, posted messages to chat sites, newsgroups or online discussion forums - arguably one of the more established activities on the Internet.

The share of Internet users who have uploaded self-created text, images, photos, videos, or music to any website to be shared, is equally impressive with $42 \%$ (in the total sample). $22 \%$ have designed or maintained an own website, and 14\% run their own blog.

Taken together, Internet users who have contributed self-created content in the 3 months prior to the survey make up $51 \%$ of the sample. If engagement on chat sites, newsgroups or discussion forums and creating a profile on a social networking site are added, the share (which may be dubbed "participative web users", see OECD, 2006) rises to $74 \%$. 
Further research is needed to explore whether such participative behaviour is novel in the sense that the Internet (and increasingly also mobile networks, see Ling, 2008) liberates creativity which before was unable to find expression.

\section{ICTs and Active Participation in Civil Society}

Research into social capital is concerned, among other things, with group membership as an indicator for civil participation and individual-level investment in social capital, usually outside the sphere of work. The survey explored group membership as well as the ways in which respondents communicate with other people in the group(s) they are member of. According to the results, $65 \%$ have been members of any type of group (business or professional association; a sport club or league; a religious organization; a hobby group or club; a neighbourhood, school, charity, voluntary or any other local group; a political or activist group; or any other group or organization) in the three years prior to the survey. Once we check whether respondents have actively taken part in decision-making and discussion within any group they are member of, we find that one in four in the total sample is a passive group member only; only $13 \%$ of the total sample are frequently participating in decisionmaking and discussions (at least 2-3 times per week).

What is the influence of using ICT on active group membership? It has been argued that extensive use of ICTs is detrimental for civil participation, as face-to-face contacts are replaced by media-poor ICTmediated contacts, such as via e-mail, chat or instant messaging (e.g. Putnam, 2000). Our findings, however, show that strong use of e-mails and other ICT for making contacts within groups goes handin-hand with a stronger participation in day-to-day decision-making within these groups (see Table 5).

Table 5: Relationship between active group membership and ICT use (\% of those with group membership)

\begin{tabular}{|c|c|c|c|c|c|}
\hline \multirow[t]{2}{*}{ - } & \multicolumn{4}{|c|}{ Use of e-mail, etc for contacting group members } & \multirow[b]{2}{*}{$\begin{array}{c}\text { Total } \\
\text { sample }\end{array}$} \\
\hline & Never & $\begin{array}{c}\text { Several } \\
\text { times per } \\
\text { year to once } \\
\text { a month }\end{array}$ & $\begin{array}{l}\text { About once } \\
\text { a fortnight } \\
\text { to once a } \\
\text { week }\end{array}$ & $\begin{array}{l}\text { At least 2-3 } \\
\text { times a } \\
\text { week }\end{array}$ & \\
\hline Passive group membership only & 74.6 & 36.3 & 22.8 & 15.2 & 37.6 \\
\hline $\begin{array}{l}\text { Active group membership } \\
\text { (participation in decision making) } \\
\text { several times per year to once a month }\end{array}$ & 14.6 & 44.9 & 27.5 & 13.0 & 21.3 \\
\hline $\begin{array}{l}\text { Active group membership } \\
\text { (participation in decision making) } \\
\text { about once a fortnight to once a week }\end{array}$ & 7.7 & 13.5 & 35.9 & 28.1 & 21.5 \\
\hline $\begin{array}{l}\text { Active group membership } \\
\text { (participation in decision making) } \\
\text { at least 2-3 times a week }\end{array}$ & 3.1 & 5.2 & 13.8 & 43.7 & 19.6 \\
\hline Total & 100 & 100 & 100 & 100 & 100 \\
\hline
\end{tabular}

What is more, additional analysis showed that this correlation is stronger than the association between face-to-face meetings within groups and participation in day-to-day decision-making within these groups. This suggests that e-mail is indeed a powerful tool for active participation in civil society.

Other research has suggested that it is "those who tend to be introverted [who] find their social contacts expanded via the information relative to their nonsurfing counterparts.[...] This means that being an Internet user is itself a source of online sociability" (Katz \& Rice, 2002, p. 264). Evidence for this proposition was recently provided by Hampton (2007) who carried out longitudinal research in four Boston (USA) neighbourhoods. Transformational impact could therefore be diagnosed in cases where ICT use is associated with civil participation, and where such participation would not, or only to a lesser extent, take place through traditional ways of communication only.

According to our own survey data, $8 \%$ of respondents who are active members of a group meet with other people in these groups less often than "several times per year". Of these $(n=106)$, more than one 
in three has e-mail contact with other group members at least 2-3 times per week, and more than one in two have such e-mail contact at least once a fortnight.

\section{Perceptions about the effect of the Internet on living conditions in regions}

The TRANSFORM survey attempted to gauge whether applications of the Internet are perceived as having had a positive effect on living conditions within regions, and whether there are differences in this regard between regions which may be explained by different ICT-related regional policies. For this purpose two questions with similar sets of items were applied:

ü A question on perceived conditions in the NUTS2 region for a) Finding a good job, (b) Getting high-quality education, (c) Engaging in adult/further education and lifelong learning, (d) Setting up an own business, (e) Making your voice heard in regional politics and public life, (f) Enjoying leisure time, (g) Enjoying a high quality of life;

ü And a second question as follows: "Some people think that the Internet has an influence on the living and working conditions in Europe's regions, others think that this is not the case. In the past three years, what kind of influence would you say the Internet has had on the general conditions in your region regarding ...", then using the same set of items as above.

Results from the first question (Table 6) suggest that there are indeed significant differences in living conditions between regions as perceived by the resident population. In general, these differences confirm what is to be expected from the differences as they show up in general regional development indicators. For example, in most regions with unemployment rates much above the EU average (Extremadura, Thüringen, Vychodne Slovensko) the perceived conditions for finding a good job are worse than average. An exception here are the Polish regions, which may reflect the fact that respondents can be expected to have - when compared to the rest of the population - very good ICT skills, the labour market for which is much more favourable than for low-qualified Polish workers.

Table 6: Perceived living conditions in own region (means on 10-point scale with $1=$ very good, $10=$ very bad)

\begin{tabular}{|c|c|c|c|c|c|c|c|c|}
\hline & & 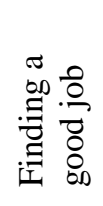 & 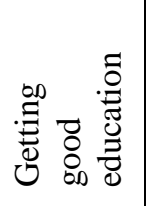 & 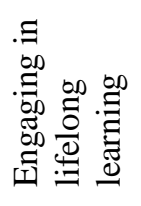 & 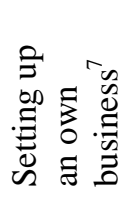 & 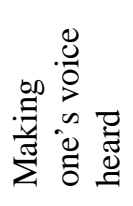 & 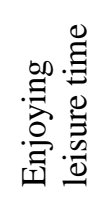 & 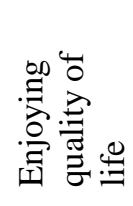 \\
\hline Schleswig-Holstein & $\mathrm{DE}$ & 5.61 & 4.03 & 4.36 & 5.01 & 4.97 & 2.85 & 3.32 \\
\hline Thüringen & $\mathrm{DE}$ & 6.60 & 4.63 & 5.04 & 5.64 & 5.79 & 3.97 & 4.84 \\
\hline Emilia-Romagna & IT & 4.55 & 4.00 & 4.23 & 4.76 & 5.11 & 3.86 & 4.27 \\
\hline Malopolskie & PL & 4.26 & 2.48 & 3.23 & 3.94 & 5.24 & 3.07 & 3.50 \\
\hline Pomorskie & PL & 3.87 & 2.75 & 3.41 & 3.77 & 5.05 & 3.24 & 3.49 \\
\hline Bratislavsky Kraj & SK & 2.65 & 2.27 & 2.59 & 2.82 & 3.00 & 2.72 & 3.00 \\
\hline Vychodne Slovensko & SK & 7.08 & 3.90 & 4.72 & 5.61 & 5.41 & 4.40 & 6.10 \\
\hline Navarra & ES & 4.29 & 3.20 & 3.92 & 4.43 & 5.82 & 3.67 & 3.39 \\
\hline Extremadura & ES & 6.06 & 4.77 & 5.13 & 5.39 & 5.40 & 4.20 & 4.08 \\
\hline Mellersta Norrlland & SE & 5.49 & 4.00 & 3.92 & 4.06 & 4.87 & 2.73 & 3.01 \\
\hline South Yorkshire & UK & 5.17 & 4.49 & 4.13 & 4.79 & 6.22 & 4.12 & 4.73 \\
\hline East Anglia & UK & 5.41 & 4.31 & 4.22 & 4.55 & 6.06 & 3.87 & 4.04 \\
\hline Total sample & & 5.13 & 3.79 & 4.12 & 4.54 & 5.31 & 3.57 & 3.96 \\
\hline
\end{tabular}

Data source: TRANSFORM 12 Region Internet User Survey

Apart from the difficult situation in some regions with regard to job availability, the most problematic area of the ones included in the question appears to be political and civil participation, i.e. "making one's voice heard in regional politics and public life". In two countries there are marked differences between regions in this regard: In Germany, where the less favourable score for Thüringen reflects the

7 Only respondents who have made some first-hand experience with self-employment (i.e. either considered self-employment for themselves, or knowing somebody personally who started a business in last 3 years) 
wide-spread disengagement with politics to be found in Eastern Germany, and in Slovakia, where the much more favourable value for the capital region is indicative of the fact that Bratislava is the clear centre of policy-making for the whole country.

Against this background, how do Internet users in the 12 regions perceive the influence of the Internet in their particular region so far?

Table 7: Perceived effect of the Internet on living conditions in own region (Very positive or positive effect ${ }^{8}$ in $\%$ of total sample per region)

\begin{tabular}{|c|c|c|c|c|c|c|c|c|}
\hline & & 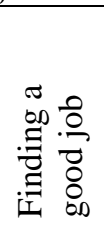 & 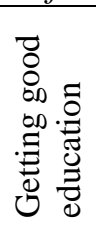 & 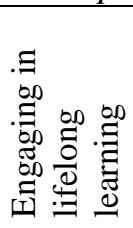 & 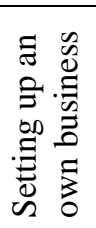 & 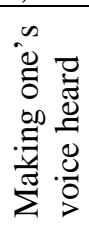 & 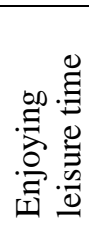 & 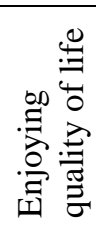 \\
\hline Schleswig-Holstein & $\overline{\mathrm{DE}}$ & 52.9 & 48.2 & 50.7 & 42.3 & 30.7 & 58.9 & 45.8 \\
\hline Thüringen & $\overline{\mathrm{DE}}$ & 47.2 & 42.8 & 39.7 & 44.1 & 29.2 & 60.0 & 42.8 \\
\hline Emilia-Romagna & IT & 59.4 & 65.2 & 62.7 & 54.2 & 48.1 & 70.7 & 49.1 \\
\hline Malopolskie & PL & 74.6 & 85.6 & 67.5 & 61.8 & 44.5 & 81.4 & 63.4 \\
\hline Pomorskie & PL & 75.0 & 78.4 & 69.3 & 59.0 & 48.9 & 79.2 & 66.5 \\
\hline Bratislavsky Kraj & SK & 86.9 & 80.4 & 76.2 & 77.4 & 56.0 & 84.0 & 66.4 \\
\hline Vychodne Slovensko & SK & 64.2 & 70.4 & 58.2 & 54.7 & 38.6 & 68.3 & 46.7 \\
\hline Navarra & ES & 49.3 & 52.1 & 44.2 & 43.4 & 36.8 & 67.0 & 50.2 \\
\hline Extremadura & ES & 44.8 & 48.2 & 45.7 & 46.4 & 40.8 & 61.9 & 47.8 \\
\hline Mellersta Norrlland & SE & 57.3 & 58.9 & 57.5 & 56.6 & 50.6 & 52.7 & 51.4 \\
\hline South Yorkshire & UK & 48.0 & 51.1 & 49.1 & 49.5 & 27.5 & 51.5 & 38.3 \\
\hline East Anglia & UK & 50.9 & 52.5 & 51.0 & 52.8 & 28.7 & 61.0 & 49.0 \\
\hline Total sample & & 58.1 & 60.1 & 55.0 & 53.4 & 39.5 & 65.9 & 51.0 \\
\hline
\end{tabular}

Data source: TRANSFORM 12 Region Internet User Survey

As Table 7 shows when compared to Table 6, those aspects of living conditions which are currently perceived, on average, to be most positive (education and training, enjoying leisure time) are also those where the highest share of respondents think that the Internet has made things better in their region. This pattern shows throughout, with the exception of conditions for "finding a good job", where the current situation is considered, on average, as quite bad, but where the Internet is perceived as having had a significant positive effect by $58 \%$ of all respondents.

While much has been made of the Internet's potential to improve direct participation of citizens in day-to-day policy-making and in civil society, the results from the survey indicate that it is proving difficult to translate such potential into reality. Only $40 \%$ of respondents think that the Internet has improved conditions for this in their region - much less than for all the other aspects of living conditions listed. It appears that those regions, in particular, which suffer from wide-spread disengagement with politics, such as Thüringen in Eastern Germany, are also the least successful in applying the Internet for the purpose of improving the situation. In contrast, every second respondent from the Swedish region Mellersta Norrlland states that the Internet has improved conditions for political participation - roughly the same share than those who see a positive effect for the other aspects of living conditions.

A multivariate OLS regression was carried out to analyse the factors which explain differences in the extent to which individuals have experienced a positive effect of the Internet on overall living conditions in their region.

The dependent variable is:

ü Factor score constructed from seven items asking about the perceived effect of the Internet on: a) Finding a good job, (b) Getting high-quality education, (c) Engaging in adult/further education and

8 Values "1" and "2" on 5-point-scale from "very positive" to "very negative" 
lifelong learning, (d) Setting up an own business, (e) Making your voice heard in regional politics and public life, (f) Enjoying leisure time, (g) Enjoying a high quality of life in the resident NUTS2 region.

As independent variables, three groups of variables were considered:

ü Socio-demographic variables (age, gender, region, still studying yes/no, educational attainment, employment status, household type);

ü Social context (trust; active group membership; size of network of personal ties; diversity of network of personal ties; first-hand experience with self-employment);

ü Internet experience variables (year started using Internet, hours Internet use per day, multilocation Internet use, providing help about computers to others);

ü Type of Internet usage (Importance of different uses of the Internet for private life, uptake of participative web services).

The results are presented in Table 8 .

Controlling for contextual factors such as socio-demographics, we find a significant positive influence of uptake of participative Internet services (typically referred to as Web 2.0 applications), here defined as comprising: Posting messages to newsgroups; Creating or maintaining own weblog; Uploading selfcreated text, images, photos, videos, music and so forth to any website to be shared; Creating a profile on a social networking site; and designing or maintained a website.

Among the social context variables, a significant explanatory factor is trust in people in the neighbourhood and trust in the willingness of people in the region to help each other (but not general trust).

Of the socio-demographic variables, the results indicate that the following groups are significantly more likely to perceive a positive impact of the Internet on living conditions within their NUTS2 region: people who are not unemployed; men; and - in particular - Internet users in the Polish regions in the sample, Emilia-Romagna and the Bratislava region, and also - to a lesser extent - the Mellersta Norrland, Eastern Slovakia and East Anglia, when compared to the rest of the regions.

The data indicate a significant degree of variation concerning the extent to which people feel that the Internet has made a real difference to living conditions in their resident region. In most cases, these differences appear to be between countries rather than between regions within the same countries although care must be taken as the number of regions covered by the analysis is too small to allow generalisation. The effect of the Internet is felt most strongly by Internet users in the New Member States, especially in the Bratislava region which has seen spectacular growth rates in recent years. Among regions from the Old Member States, there is some evidence that Emilia Romagna has succeeded better than the other regions in perceivably improving living conditions with the help of ICT. Mellersta Norrland and East Anglia also emerge as "good performers", although the evidence is weaker (but still significant).

The role of trust is found to be of special relevance for the extent to which a positive impact of the Internet is felt within regions. This does not apply to general trust, but to trust in people in the immediate region and the belief that people are willing to help each other out. It appears that the Internet requires a certain degree of community-level social capital (as indicated by high levels of trust) in order to yield the positive effects on living conditions which are hoped for by policy-makers.

Finally, the extent to which individuals have taken up participative Web2.0 applications is significantly and positively associated with perceived Internet-enabled improvements in living conditions. It can be assumed that people who believe in the power of the Internet to make a difference are also more enthusiastic about new Internet services, and that - vice versa - experience of advanced Internet applications is likely to make people more aware of the difference which the Internet has already made to living conditions. It follows that activities which strengthen awareness among regional stakeholders, including society at large, about the possible benefits to be derived from latestgeneration ICTs can exert a positive influence on regional development. 
Table 8: Association between Internet's perceived effect on living conditions within the NUTS2-region, other ICT-related, social and contextual factors (OLS Regression)

\section{Dependent Variable: Influence of}

internet on life

\begin{tabular}{|c|c|c|c|c|c|}
\hline & B & Std. Error & Beta & $\mathrm{t}$ & Sig. \\
\hline (Constant) & 11.64 & 11.74 & & 0.99 & 0.32 \\
\hline qs1_1 Age & 0.00 & 0.00 & -0.06 & -2.43 & 0.02 \\
\hline qs2 Gender & 0.17 & $\mathbf{0 . 0 4}$ & 0.09 & 4.41 & $\overline{0.00}$ \\
\hline \multicolumn{6}{|l|}{ Region (reference Thuringia) } \\
\hline SchleswigH & 0.13 & 0.09 & 0.04 & 1.52 & 0.13 \\
\hline EmiliaRomagna & 0.54 & 0.09 & 0.16 & 6.19 & 0.00 \\
\hline Malopolskie & 0.65 & 0.09 & 0.20 & 7.16 & 0.00 \\
\hline Pomorskie & 0.60 & 0.09 & 0.18 & 6.62 & 0.00 \\
\hline BratislavskyKraj & 0.82 & 0.10 & 0.19 & 7.93 & 0.00 \\
\hline VychodneSlovensko & 0.30 & 0.11 & 0.07 & 2.78 & 0.01 \\
\hline Navarra & 0.20 & 0.09 & 0.06 & 2.25 & 0.02 \\
\hline Extremadura & 0.12 & 0.09 & 0.04 & 1.40 & 0.16 \\
\hline MellerstaNorrland & 0.29 & 0.09 & 0.08 & 3.04 & 0.00 \\
\hline SouthYorkshire & 0.20 & 0.09 & 0.06 & 2.26 & 0.02 \\
\hline EastAnglia & 0.29 & 0.09 & 0.08 & 3.19 & 0.00 \\
\hline Still studying & 0.13 & 0.07 & 0.05 & 1.76 & 0.08 \\
\hline \multicolumn{6}{|l|}{$\begin{array}{l}\text { Education: } \text { reference }=\text { lower secondary and } \\
\text { less }\end{array}$} \\
\hline Upper secondary education & 0.04 & 0.06 & 0.02 & 0.56 & 0.57 \\
\hline Tertiary / other $21+$ education & 0.01 & 0.07 & 0.00 & 0.10 & 0.92 \\
\hline \multicolumn{6}{|l|}{ Employment status: reference $=$ inactive } \\
\hline Employee (incl. family workers) & -0.14 & 0.08 & -0.07 & -1.75 & 0.08 \\
\hline Self-employed & -0.16 & 0.10 & -0.05 & -1.64 & 0.10 \\
\hline Unemployed & -0.27 & 0.10 & -0.07 & -2.74 & 0.01 \\
\hline Student (not in the labour force) & -0.24 & 0.11 & -0.09 & -2.14 & 0.03 \\
\hline \multicolumn{6}{|l|}{$\begin{array}{l}\text { Household type: reference }=\text { single } \\
\text { household }\end{array}$} \\
\hline $2+$ person household, no kids $<16$ & 0.05 & 0.06 & 0.02 & 0.71 & 0.48 \\
\hline Household with children $<16$ & 0.03 & 0.07 & 0.02 & 0.48 & 0.63 \\
\hline $\begin{array}{l}\text { Agreement: Generally speaking, most } \\
\text { people can be trusted. }\end{array}$ & 0.00 & 0.01 & 0.00 & $\begin{array}{c}-0.01 \\
\end{array}$ & 0.99 \\
\hline $\begin{array}{l}\text { Agreement: Most people in my } \\
\text { neighbourhood can be trusted. }\end{array}$ & 0.05 & 0.01 & 0.13 & 4.19 & $\mathbf{0 . 0 0}$ \\
\hline $\begin{array}{l}\text { Agreement: People around here are } \\
\text { really willing to help each other out. }\end{array}$ & 0.05 & 0.01 & 0.13 & 4.30 & 0.00 \\
\hline Active group membership & 0.09 & 0.04 & 0.05 & 2.33 & 0.02 \\
\hline Sum social ties (classes) & 0.00 & 0.01 & -0.01 & -0.36 & 0.72 \\
\hline $\begin{array}{l}\text { Diversity: Number of different occupations } \\
+ \text { ethnicity + languages among social ties }\end{array}$ & 0.02 & 0.01 & 0.06 & 2.18 & 0.03 \\
\hline Propinquity to self-employment & 0.11 & 0.05 & 0.05 & 2.35 & 0.02 \\
\hline Year started using Internet & -0.01 & 0.01 & -0.02 & -1.01 & 0.31 \\
\hline Duration Internet per Day in Minutes & 0.00 & 0.00 & 0.04 & 2.05 & 0.04 \\
\hline Frequent multi-location Internet use & 0.11 & 0.04 & 0.06 & 2.49 & 0.01 \\
\hline Providing help to others than friends/family & 0.06 & 0.04 & 0.03 & 1.41 & 0.16 \\
\hline Number of Web 2.0 uses & 0.05 & 0.02 & 0.07 & 3.01 & 0.00 \\
\hline
\end{tabular}




\begin{tabular}{|c|c|c|c|c|c|}
\hline & $\begin{array}{l}\text { Sum of } \\
\text { Squares }\end{array}$ & & Mean Square & $\mathrm{F}$ & Sig. \\
\hline Regression & 468.5 & 33.0 & 14.2 & 20.0 & 0.000 \\
\hline Residual & 1440.3 & 2032.0 & 0.7 & & \\
\hline Total & 1908.9 & 2065.0 & & & \\
\hline
\end{tabular}

\begin{tabular}{ccccc}
\multicolumn{2}{c}{ Model Summary } & & & \\
\hline $\mathrm{R}$ & $\mathrm{R}$ Square & & Adjusted R Square & Std. Error of the Estimate \\
\hline & 0.50 & 0.25 & 0.23 & 0.84 \\
\hline & \multicolumn{3}{c}{ Data source: TRANSFORM 12 Region Internet User Survey }
\end{tabular}

\section{Conclusions and outlook}

This chapter has attempted to present a concept for the analysis and measurement of transformational uses of ICT, mainly at the sub-national (e.g. regional) level. The chapter focused on use of ICT by individuals in their roles as citizens, workers, learners, patients, consumers, and so forth. We have argued that here, the transformational potential of ICTs is rooted in its effect in terms of empowerment of users, i.e. "the process of granting people the power to take responsible initiatives to shape their own life and that of their community or society in economic, social and political terms" (CEC 2005b, p. 32). Finally, the chapter discussed some results of an Internet user survey which was conducted in early 2008 in 12 selected regions in the EU, and which was used to pilot indicators for capturing transformational use of ICTs by individuals and to gain insight into perceptions and determinants of such transformational usage.

Our own analysis of the survey data supports the claim that the Internet is indeed having a tangible, and arguably transformative, impact" on users. This effect makes itself felt through an instrumental, and often essential, role of the Internet in major, transformative decisions in life; through Internetenabled participation in forms of creativity and socialising; through easier, frequent participation in decision-making within social groups; and through improvement in living conditions in EU regions, especially with regard to the ability to find a good job.

With regard to the measurement of transformational use of ICT - in particular as far as the regional level is concerned - currently available indicators in the EU are not sufficient for benchmarking purposes. The obvious first step must be to make progress towards availability of basic indicators of ICT infrastructure, uptake and use for all NUTS2 regions. Eurostat, National Statistical Institutes and the regions need to join together and explore ways in which the data can be supplied in a cost-effective and reliable way. Financial support should be given to regions that participate on their own initiative in harmonised data collection. If needed, options should be explored to cut down the level of detail in other areas of statistical measurement to free up funds needed for the collection of KBS statistics at regional level.

Once such basic indicators are available - as they are already in a small number of EU regions which have set up their own KBS observatories (cf. UNDERSTAND 2006) - there is an obvious need to supplement indicators which mainly focus on technology (such as the i2010 benchmarking indicators) with measures which focus on impacts. In particular, new indicators are needed for benchmarking the capacity (of individuals, firms and regions) to 'unlock' the transformational potential of ICTs, and the actual practice in doing so.

For capturing transformational uses, we have suggested to group individuals' uses of ICT according to a classification of spheres of everyday life activities. This enables a better informed analysis of changes caused or enabled by the application of ICTs. In each of these spheres, transformational use of technology can be operationalised as applications for purposes which have a significant importance for the lives of people, and which would not have been possible without the help of ICTs such as the Internet. In particular, this refers to uses which increase the capability of people to build and maintain social ties (network capital and social capital), to continuously engage in learning and activities related 
to innovation, and to get empowered by having a bigger say in decision-making which is likely to concern their lives.

In key areas where transformational use of ICT can play a significant role in fostering social and economic development in regions - such as those related to the notion of social capital - the current status of evidence and theory building is not, however, robust enough to allow for the definition of benchmarking indicators in the sense of statistical measures where "more" is always "better". This means that there is a need for more research into the soft factors (including social capital) underlying success in regional development, and the way such factors are associated with patterns of use of ICTs.

\section{Acknowledgements}

The research was carried out in the context of a project (TRANSFORM) within the EU's $6^{\text {th }}$ Framework Programme. The project consortium gratefully acknowledges funding by the European Commission, DG Information Society \& Media. All views expressed in this document, however, are those of the author and do not necessarily reflect the views of the European Commission. More information about the project can be found at www.transform-eu.org.

\section{References}

Alampay, E. A. (2006). Beyond access to ICTs: Measuring capabilities in the information society. International Journal of Education and Development using Information and Communication Technology (IJEDICT), 2(3), 4-22.

Annetta, L. A. (ed.)(2008). Serious Educational Games: From Theory to Practice. Rotterdam: Sense.

Ball-Rokeach, S.J. (1985). The Origins of Individual Media-System Dependency: A Sociological Framework. Communication Research, 12(4), 485-510.

Benkler, Y. (2006). The Wealth of Networks: How Social Production Transforms Markets and Freedom. New Haven, CT \& London: Yale University Press.

Bianchi, A., Barrios, S., Cabrera, M., Cachia, R., Compañó, R., Malanowski, N., Punie, Y., Turlea, G., Zinnbauer, D., \& Centeno, C. (2006). Revisiting eInclusion: from Vision to Action. Working Paper, Sevilla: Institute for Prospective Technology Studies.

Boase, J., Horrigan, J. B., Wellman, B., \& Rainie, L. (2006). The Strength of Internet Ties. Report, Washington, DC: Pew Internet \& American Life Project.

Castells, M. (2001). The Internet Galaxy - Reflections on the Internet, Business, and Society. Oxford and New York: Oxford University Press.

Castells, M., Fernandez-Ardeval, M., Linchuan Qiu, J., \& Sey, A. (2004). The Mobile Communication Society - A Cross-cultural Analysis of Available Evidence on the Social Uses of Wireless Communication Technology. Report, Annenberg Research Network on International Communication.

Castronova, E. (2005). Synthetic Worlds: The Business and Culture of Online Games. Chicago: University of Chicago Press.

Commission of the European Communities (CEC)(2005a). Information Society Benchmarking Report. Brussels: European Commission.

Commission of the European Communities (CEC)(2005b). Proposal for a Recommendation Of The European Parliament And Of The Council on Key Competences for Lifelong Learning. Brussels: European Commission.

Commission of the European Communities (CEC)(2005c). i2010 - A European Information Society for growth and employment. Communication from the Commission to the European Parliament, the European Economic and Social Committee and the Committee of the Regions, COM(2005) 229 final, Brussels: European Commission. 
Cordella, Antonio (2006). Transaction costs and information systems: Does IT add up?. Journal of Information Technology, 21, 195-202.

Cornford, J., Richardson, R., Sokol, M., Marques, P., \& Gillespie, A. (2006). Transformation of Regional Societies Through ICTs: State(s) of the Art(s) - A Discussion Document. Bonn: TRANSFORM Consortium.

Dahlberg, L. (2001). Democracy via Cyberspace: Mapping the Rhetoricsand Practices of Three Prominent Camps. New Media and Society, 3(2), 157-177.

Dutton, W. H. (2005). The Internet and Social Transformation: Reconfiguring Access. In Dutton, W.H., Kahin, B., O'Callaghan, R. and Wyckoff, A.W. (Ed.). Transforming Enterprise: The Economic and Social Implications of Information Technology (pp. 375-397). Cambridge, MA and London: MIT Press.

Dutton, W. H., \& Helsper, E. J. (2007). The Internet in Britain: 2007. Oxford (UK): Oxford Internet Institute, University of Oxford.

Eurostat (2006) Methodological Manual for Statistics on the Information Society, Survey year 2006, v2.1. Luxembourg: Eurostat.

eUSER Consortium (2006). Report on Current Demand/Supply Match and Relevant Developments. Project deliverable, Bonn: Empirica.

Feldmann, V., \& Zerdick, A. (2005). E-Merging Media: The Future of Communication. In Zerdick, A. et al. (Ed.). E-Merging Media: Communication and the Media Economy of the Future (pp. 19-29). Berlin, Heidelberg and New York: Springer.

Field, J. (2003). Social Capital. London \& New York: Routledge.

Granovetter, M. (1973). The Strength of Weak Ties. American Journal of Sociology, 91, 1360-1380.

Hampton, K. N. (2007). Neighborhoods in the Network Society - The e-Neighbors Study. Information, Communication \& Society, 10(5), 714-748.

Harper, R., \& Kelly, M. (2003). Measuring Social Capital in the United Kingdom. London: ONS.

Hill, K. A. \& Hughes, J. (1998). Cyberpolitics: Citizen Activism in the Age of the Internet. New York: Rowman and Littlefield.

Huys, R., \& Ramioul, M. (2007). Measuring the degree of organisational transformation, A methodological benchmark of organisation surveys. Sotziologuicheski problemi, 40, 58-80.

i2010 High Level Group (i2010 HLG)(2006). i2010 Benchmarking Framework, Issue No. 1. Brussels: European Commission.

Jung, J.-Y., Qiu, J. L., \& Kim, Y.-C. (2001). Internet Connectedness and Inequality: Beyond the "Divide". Communication Research, 28(4), 507-35.

Katz, J. E., \& Rice, R. E. (2002). Social Consequences of Internet Use - Access, Involvement, and Interaction. Cambridge, Mass and London: MIT Press.

Ling, R. (2008). New Tech, New Ties: How Mobile Communication Is Reshaping Social Cohesion. Cambridge, Mass and London: MIT Press.

MacKenzie, D., \& Wajcman, J. (eds)(1999). The Social Shaping of Technology. $2^{\text {nd }}$ edition. Buckingham: Open University Press.

Malone, T. W. (2004). The Future of Work. Boston, MA: Harvard Business School Press.

Malone, T. W., J. Yates, \& Benjamin, R. I. (1987). Electronic Markets and Electronic Hierarchies. Communications of the ACM, 30, 484-497

Mansell, R. (2002) New Media and the Power of Networks. Proceedings of DSIage2002, Cork, 4-7 July, 2002 (pp. 21-28).

Murero, M., Rice, R. E., Katz, J. E., Dutta-Bergman, M., \& Banerjee, I. (eds.)(2006). The Internet and Health Care: Theory, Research and Practice. Philadelphia, PA: Lawrence Erlbaum Associates. 
Nahapiet, J., \& Ghoshal, S. (1998). Social capital, intellectual capital, and the organizational advantage. Academy of Management Review 23(2), 242-266.

Nordflex Group (1999) Flexibility Matters - Flexible Enterprises in the Nordic Countries. Stockholm: NUTEK.

Nurmela, J. (2006). Does the Use of Communication Media Add to Social Capital? In Iisakka, L. (Ed.), Social Capital in Finland - Statistical Review (pp. 63-72). Helsinki: Statistics Finland.

Nurmela, J. et al. (2004). Finnish People's Communication Capabilities in Interactive Society of the 2000s (Reviews 2004/7). Helsinki: Statistics Finland.

OECD (2001). Knowledge, Work Organisation and Economic Growth, Labour Market and Social Policy (Occasional Papers No. 50). Paris: OECD.

OECD (2004). The Economic Impact of ICT - Measurement, Evidence and Implications. Paris: OECD.

OECD (2007). Participative Web: User-Created Content. Working Party on the Information Society, Online Document. Paris: OECD.

OECD (2008). Guide to Measuring the Information Society. Working Party on the Information Society, Online Document, Paris: OECD.

Parent-Thirion, Agnès; Fernández Macías, Enrique; Hurley, John; Vermeylen, Greet (2007). Fourth European Working Conditions Survey. Luxembourg: Office for Official Publications of the European Communities.

Picot, A., Reichwald, R. \& Wigand, R.T. (2003). Die grenzenlose Unternehmung. $5^{\text {th }}$ edition. Wiesbaden: Gabler.

Putnam, R. (2000). Bowling Alone. The Collapse and Revival of American Community. New York: Simon \& Schuster.

Rheingold, H. (2000). The Virtual Community - Homesteading on the Electronic Frontier. $2^{\text {nd }}$ edition. Cmabridge, MA and London: MIT Press.

Savage, P. (2001). New Forms of Work Organisation - The Benefits and Impact on Performance. thematic paper presented to DG Employment \& Social Affairs by The European Work Organisation Network (EWON). Brussels: European Commission.

Sen, A. (1999). Development as Freedom. Oxford, New York: Oxford University Press.

Sheller, M. and Urry, J. (2006). The New Mobilities Paradigm. Environment and Planning A, 38, 207226.

Smith, H. \& Fingar, P. (2003). IT Doesn't Matter - Business Processes Do: A Critical Analysis of Nicholas Carr's I.T. Article in the Harvard Business Review. Tampa, FL: Meghan-Kiffer Press.

Tapscott \& Williams (2007). Wikinomics - How Mass Collaboration Changes Everything. New York, NY: Portfolio.

Tuomi, I. (2002). Networks of Innovation: Change and Meaning in the Age of the Internet. Oxford and New York: Oxford University Press.

Tuomi, I. (2006). The Future of Learning in the Knowledge Society - Disruptive Changes for Europe by 2020. In Punie, Y. et al. (Ed.), The Future of ICT and Learning in the Knowledge Society. Luxembourg: Office for Official Publications of the European Communities.

UNDERSTAND Consortium (2006). Methodology Handbook. Project report. Swansea: University of Wales.

van Dijk, J.A.G.M. (2005). The Deepening Divide - Inequality in the Information Society. Thousand Oaks, London and Delhi: SAGE.

Wellman, B. (2001). Computer networks as Social Networks, Science, 293, 2031-2034. 
Zittrain, J. (2006). The Generative Internet (Working Paper 28/2006). University of Oxford, Faculty of Law. 


\section{Key Terms and Their Definitions}

Empowerment is "the process of granting people the power to take responsible initiatives to shape their own life and that of their community or society in economic, social and political terms" (CEC 2005b, p. 32).

Participative web: "The 'participative web' is the most common term and underlying concept used to describe the more extensive use of the Internet's capabilities to expand creativity and communication. It is based on intelligent web services and new Internet-based software applications that enable users to collaborate and contribute to developing, extending, rating, commenting on and distributing digital content and developing and customising Internet applications" (OECD 2007, p. 17).

Social Capital: "By making connections with one another, and keeping them going over time, people are able to work together to achieve things that they either could not achieve by themselves, or could only achieve with great difficulty. People connect through a series of networks and they tend to share common values with other members of these networks; to the extent that these networks constitute a resource, they can be seen as forming a kind of capital" (Field, 2003, p.5).

Social networking: The term is used here for desribing users of social network services, which are applications for building online communities of people who share interests, preferences or activities. Typically, social networking makes use of web based tools which provide a variety of ways for users to interact, such as e-mail and instant messaging services.

Transformational change denotes change processes which are establishing fundamentally new ways to achieve progress towards achieving the basic goals of an agent, such as a private household, worker, business, or regional government. As such, transformational change is the opposite of incremental change. Transformational change can also be understood to be about effectiveness rather than about efficiency.

Transformational uses of ICT: Applications of ICT which enable users to obtain goals which would be unobtainable without these technologies. This refers, in particular, to uses which have an empowering effect on users in their role as citizens, workers, learners, patients, consumers, and so forth.

User-Created Content is a term which is used in connection to the notion of the "participative web". The OECD (2007, p. 18) proposes three central characteristics as defining properties of user-created content: publication requirement (the work is made publically available rather than exchanged between individuals); a minimum degree of creative effort; and creation outside of professional routines and practises. 


\section{The authors}

KARSTEN GAREIS is senior researcher at empirica, Bonn. His main fields of interest are the way Information Society Technologies impact on ways of working, social inclusion, and regional development. In recent years he was responsible for research on user orientation of public online services in the European Commission funded eUSER project. As project coordinator he oversaw the BISER and TRANSFORM projects, which looked into transformational use of ICTs in EU regions and its relation to regional innovation cultures, economic performance and social cohesion.

TOBIAS HÜSING is a researcher at empirica. His educational background is in economics and sociology. Tobias specialises in quantitative empirical research and has been responsible for survey methodology and statistical analysis in a variety of large scale pan-European projects. His work addresses all kinds of questions relating to gauging and benchmarking the information society from a policy perspective. Recent work includes various perspectives of the Information Society: that of patients and health care providers, schools and teachers, senior citizens, regional development, specific industries and SMEs, and of citizens and users in general. In many of these, his specific interest has been in questions of eInclusion, the digital divide. Apart from developing these for empirica projects, Tobias has worked on questionnaires and methodologies for Eurostat and the European Commission. 